\title{
Kajian Penggunaan Incinerator Untuk Mengelola Limbah Medis Padat di Denpasar
}

\author{
I.G.A.B. Adiputra ${ }^{1}$,I.A.D. Giriantari ${ }^{2}$,I.N.S. Kumara ${ }^{3}$ \\ Submission: 09-10-2019, Accepted: 14-10-2019
}

\begin{abstract}
- one method for treating hospital toxic waste is by an incinerator. Incinerators burn hospital solid medical waste at high temperatures. Many hospitals have to transport their toxic waste to third party locations located outside Bali. In Bali, there are 62 hospitals with 6,195 inpatient rooms with 5,584,310 patient visits per year resulting in large quantities of toxic waste. Hospitals in Bali must send their waste to Java, which causes high costs and problems in transportation. One solution is to develop small-scale incinerators near hospital locations. This project is funded by the Japan International Cooperation Agency and is currently the only incinerator in hospitals in Bali. This paper discusses how to treat waste in Wangaya District Hospital and specifically the use of incinerators. The discussion will cover waste management in Wangaya District Hospital, incinerator development steps, incinerator performance, and economic analysis. From the results of the emission test and the technical requirements of this incinerator have met the KLHK standards. While the economic analysis results of the incinerator at the Wangaya District Hospital were NPV Rp 15,039,352,740, IRR 33.49 months, PBP 2.74 years, PI 4.69, meaning all of the economic analyzes above are positive therefore the incinerator projects is economicilly feasible.
\end{abstract}

Keyword: Hospital, waste treatment, toxic waste, incinerator, environmental, economical feasibility, NPV, payback period, energy conservation.

Intisari- salah satu metode untuk mengolah limbah beracun rumah sakit adalah dengan incinerator. Incinerator membakar limbah medis padat rumah sakit pada suhu tinggi. Banyak rumah sakit harus mengangkut limbah beracunnya ke lokasi pihak ketiga yang lokasinya diluar Bali. Di Bali, ada 62 rumah sakit dengan 6.195 kamar inap dengan 5.584.310 kunjungan pasien pertahun sehingga menghasilkan sejumlah besar limbah beracun. Rumah sakit di Bali harus mengirim limbahnya ke pulau Jawa menyebabkan biaya yang mahal dan masalah dalam pengangkutannya. Salah satu solusinya adalah mengembangkan incinerator skala kecil di dekat lokasi rumah sakit. Proyek ini didanai oleh Japan Internasional Cooperation Agency dan saat ini merupakan satu-satunya incinerator yang ada di rumah sakit di Bali. Paper ini membahas bagaimana pengolahan limbah di RSUD Wangaya dan khususnya penggunaan incinerator. Pembahasan akan meliputi pengelolaan limbah di RSUD Wangaya, langkah-langkah pembangunan incinerator, unjuk kerja incinerator dan analisa ekonomi. Hasil uji emisi gas buang yang dikeluarkan oleh cerobong dan persyaratan teknis lainnya sudah memenuhi standar dari KLHK. Hasil analisa ekonomi incinerator di RSUD Wangaya memperlihatkan NPV Rp 15.039.352.740, IRR 33,49 bulan, PBP 2,74 tahun, $P I$ 4,69 artinya

${ }^{1}$ RSUD Wangaya Kota Denpasar, Jln. Kartini, Denpasar 80115, INDONESIA, (telp: 0361-222141, e-mail:

gungadiputra86@gmail.com)

${ }^{2}$ Jurusan Teknik Elektro, Fakultas Teknik Universitas Udayana, Jln. Kampus Bukit Jimbaran 80361 INDONESIA, (telp: 0361-

703315,e-mail: dayu.giriantari@unud.ac.id, satya.kumara@unud,ac.id)

I.G.A.B. Adiputra : Kajian Penggunaan Incinerator Untuk.... semua analisa ekonomi terpenuhi sehingga incinerator secara ekonomi adalah layak.

Kata Kunci: Rumah sakit, pengolahan limbah medis, limbah beracun, incinerator, analisa ekonomi, NPV, payback period, konservasi energi.

\section{PENDAHULUAN}

Perkembangan rumah sakit belakangan ini mengalami pertumbuhan yang meningkat seiring dengan bertambahnya jumlah penduduk dan meningkatnya pendapatan mayarakat Indonesia. Provinsi Bali berdasarkan profil kesehatan Bali 2017 yang dikeluarkan oleh Dinas Kesehatan Provinsi Bali terdapat 62 rumah sakit dengan 6.195 tempat tidur [1].

Sebagai institusi pemberi layanan kesehaan kepada masyarakat, rumah sakit juga mempunyai kewajiban untuk menjaga lingkungan disekitar rumah sakit agar tidak mengalami pencercemaran. Rumah sakit harus mampu mengelola limbahnya dengan benar salah satu cara pengelolan limbah medis padat yaitu membakar pada incinerator. Incinerator merupakan alat pemusnah sampah dengan cara pembakaran pada suhu tinggi [2]. Secara sistematis pengolahan tersebut nyaman bagi lingkungan, tetapi dalam penerapannya masih banyak yang belum memenuhi persyaratan baik secara administrasi dan teknik sehingga mengganggu lingkungan sekitar.

Kondisi pengolahan limbah medis di Indonesia akhir-akhir ini mengalami permasalahan dengan banyaknya masalah pembuangan limbah medis padat yang tidak pada tempatnya atau ilegal yang dapat membahayakan kesehatan masyarakat sekitarnya. Penunpukan sampah medis di fasilitas pelayanan kesehatan ini juga disebakan beberapa pengelola limbah medis tidak berjalan baik ini terjadi akhir tahun 2017[3].

Maka berdasarkan masalah tersebut, penulis melakukan penelitian mengenai kajian penggunaan incinerator untuk mengolah limbah medis di Denpasar, dengan tempat penelitiannya di Rumah Sakit Umum Daerah (RSUD) Wangaya Kota Denpasar. Tujuan dari penulisan paper ini untuk membahas bagaimana pengelolaan limbah di RSUD wangaya dan khususnya penggunaan incinerator. Pembahasan akan meliputi pemaparan pengolahan limbah di RSUD Wangaya, langkah langkah pembangunan incinerator, unjuk kerja incinerator dan analisa investasi.

\section{PENGELOLAAN LIMBAH B3 RUMAH SAKIT}

\section{A. Regulasi Pengelolaan Limbah B3 di Indonesia}

Kebijakan untuk mengelola limbah bahan berbahaya dan beracun atau B3 di Indonesia diatur dalam beberapa peraturan pemerintah dimana peraturan yang satu dengan yang lainnya saling melengkapi seperti berikut.

p-ISSN:1693 - 2951; e-ISSN: 2503-2372 
PP 12 JO.PP 19/1994 TENTANG PENGOLOLAAN

LIMBAH BAHAN BERBAHAYA DAN BERACUN

PP 18 JO.PP 85/1999 TENTANG PENGOLOLAAN

LIMBAH BAHAN BERBAHAYA DAN BERACUN

\section{PP 101/2014TENTANG PENGOLOLAAN LIMBAH} BAHAN BERBAHAYA DAN BERACUN

Perturan turunan yang khusus mengatur tata cara pengelolaan limbah di fasilatas kesehatan diatur pada PERMENLHK 56/2015[4],[5],[6].

\section{B. Pengolahan Limbah Rumah Sakit di Indonesia}

Metode atau teknik pengolahan limbah medis padat di unit pelayanan kesehatan di Indonesia dapat dilakukan secara thermal dan penguburan untuk limbah tertentu, ditempat yang memenuhi persyaratan. Untuk pengolahan secara thermal menggunakan peralatan: autoclave, gelombang mikro, iradiasi frekuensi dan incinerator.

Penggunaan autoclave, gelombang mikro, Iradiasi frekuensi radio harus memenuhi standar dimana ada uji validasi dan tidak bisa digunakan untuk limbah patologis, bahan kimia kadaluwarsa, radioaktif, farmasi dan sitokis. Dari metode tersebut yang paling bisa untuk mengolah hampir semua limbah Bahan Berbahaya Beracun (B3) adalah incinerator, tapi incinerator juga memiliki batasan yaitu tidak dapat mengolah limbah seperti limbah radioaktif. Hasil dari sisa pembakaran incinerator yang berupa abu bisa dibuang ke tempat penimbunan akhir atau secerud landfill [7].

Untuk limbah non medis rumah sakit pengelolaannya adalah dengan memilah, sisanya yang tidak bisa dimanfaatkan langsung dikirim ke Tempat Pembuangan Sampah (TPS) umum. Sedangkan limbah cair di rumah sakit semuanya diolah di instalasi pengolahan air Limbah ( IPAL ) rumah sakit.

Secara detail pengolahan tersebut digambarkan dari flowchart berikut :

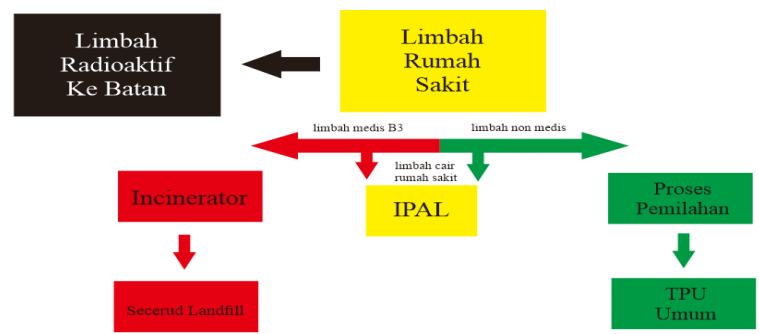

Gambar 1: Flowchart sederhana pengolahan limbah medis dan non medis rumah sakit

C. Persyaratan Incinerator Rumah Sakit di Indonesia

Untuk bisa operasionalnya incinerator di rumah sakit harus memenuhi persyartan administrasi dan persyaratan teknis. Persyaratan administrasinya antara lain: memiliki izin lingkungan, akta pendirian perusahaan, izin lokasi, Surat Izin Usaha Perdagangan (SIUP)/Izin Usaha Tetap (IUT)/Izin Usaha Industri (IUI), Izin Mendirikan Bangunan (IMB), izin penyimpanan limbah B3, izin pembuangan limbah cair .
Persyaratan teknis incinerator yang harus dipenuhi :

1. Efisiensi pembakaran sekurang-kurangnya $99,5 \%$

2. Suhu ruang bakar utama sekurang-kurangnya $800^{\circ} \mathrm{C}$

3. Suhu paling rendah $1000^{\circ} \mathrm{C}$ di ruang bakar dua dengan waktu tinggal singkat 2 detik

4. Memiliki alat pengendali pencemaran udara berupa wet scrubber atau sejenisnya

5. Ketinggian cerobong paling rendah 14 meter

6. Cerobong dilengkapi lubang pengecekan Emisi

7. Emisi atau gas buang memenuhi standar

Berikut adalah proses incinerator

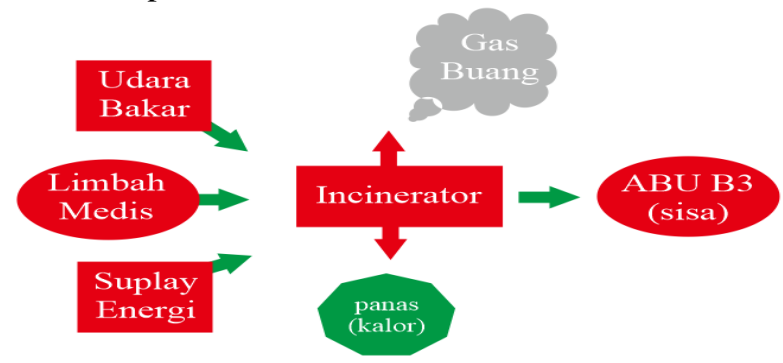

Gambar 2: Proses incinerator

\section{Wet Scrubber}

Wet scrubber merupakan alat yang digunakan untuk memisahkan partikel debu yang ada dalam udara dengan menggunakan cairan sebagai alat bantu, air merupakan cairan yang pada umumnya digunakan pada proses scrubbing. Wet scrubber dapat mengurangi polutan udara dengan penanggulangan emisi pencemar yang dihasilkan oleh gas buang incinerator. Pada umumnya wet scrubber mampu menghasilkan partikel dengan ukuran diameter $1 \mu-2 \mu$.

Berikut cara kerja wet scrubber incinerator, udara kotor yang keluar dari dalam ruang bakar incinerator mengalir ke lubang gas, lubang gas ini di atasnya dipasang sprinkler (pembuat spray air) sehingga gas buang yang melewati percikan air ini menjadi bersih dan siap dilepas ke udara bebas, sedangkan untuk sisa airnya dialirkan kemudian diolah di IPAL [8].

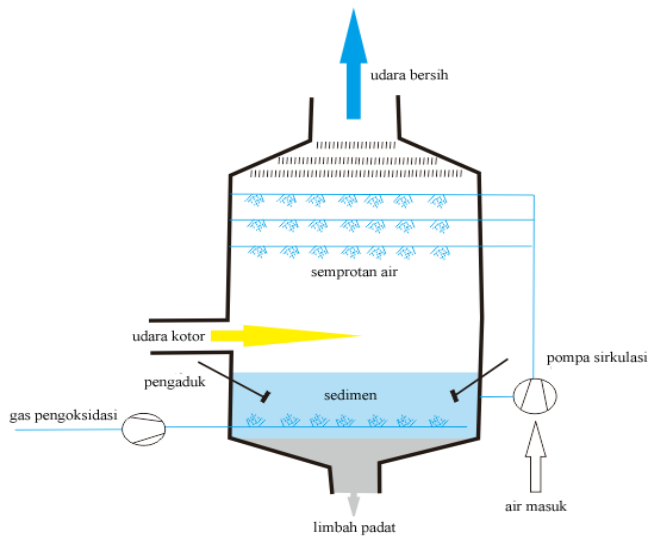

Gambar 3: Prinsip kerja Wet Scrubber

\section{E. Kondisi Incinerator Rumah Sakit di Indonesia}


Di Indonesia penggunaan incinerator di rumah sakit belum banyak karena berbagai kendala. Berdasarkan data Kementerian Lingkungan Hidup dan Kehutanan bulan Juli 2018 dari 2.800 rumah sakit di Indonesia yang memiliki ijin operasional incinerator baru 3,3\%. Sebaran pemakaian incinerator ini ada di 18 provinsi di Indonesia, dari data tersebut belum ada rumah sakit dari Bali yang memiliki izin operasional incinerator. Banyaknya fasilitas kesehatan di Indonesia tidak memiliki izin operasional incinerator disebabkan beberapa hal antara lain: tidak adanya lahan, ditolak oleh masyarakat karena mengeluarkan emisi yang menganggu dan incinerator yang tidak memenuhi persyaratan.

\section{F. Tinjauan Pelayanan Kesehatan di Bali}

Jumlah fasilitas kesehatan yang ada di Bali pada tahun 2017 adalah 62 rumah sakit dengan 6.195 jumlah tempat tidur serta jumlah pasien sebanyak 500.424. Berikut adalah perkembangan jumlah masyarakat yang dirawat di fasilitas kesehatan yang ada di Bali baik rumah sakit swasta atau pemerintah dari tahun 2014 sampai 2017.

TABEL I

KUNJUNGAN RAWAT JALAN DAN INAP PROVINSI BALI 2014 - 2017

\begin{tabular}{|c|c|c}
\hline \multirow{2}{*}{ Tahun } & \multicolumn{2}{|c}{ Jumlah kunjungan } \\
\hline 2014 & Rawat Jalan & Rawat Inap \\
\hline 2015 & 2.187 .467 & 99.999 \\
\hline 2016 & 3.517 .271 & 192.316 \\
\hline 2017 & 5.567 .332 & 328.044 \\
\hline
\end{tabular}

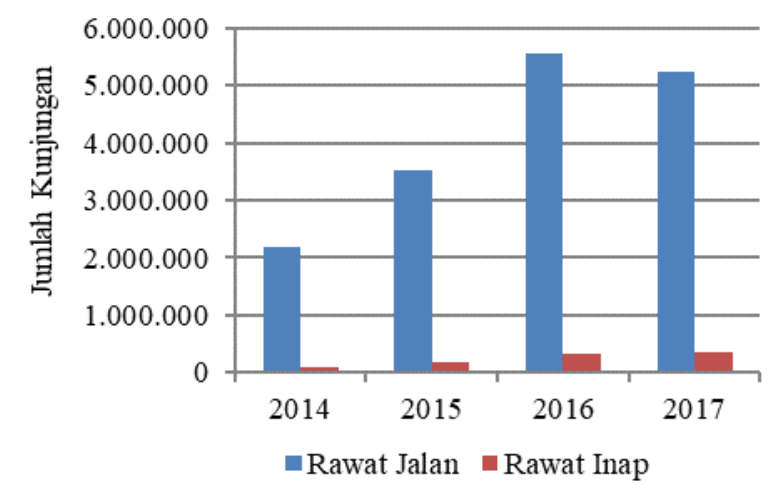

Gambar 4: Grafik kunjungan rawat jalan dan rawat inap Provinsi Bali

Dari data diatas terlihat jumlah masyarakat yang memakai fasilitas kesehatan untuk perawatan kesehatan di Bali setiap tahun mengalami peningkatan. Setiap kenaikan jumlah pasien berarti terjadi kenaikan limbah medis yang dihasilkan. Menurut kajian dan perkiraan KEMENKES RI produksi limbah medis di Indonesia $0,14 \mathrm{~kg} / \mathrm{TT}$ perhari [9]. Untuk Provinsi Bali sesuai data DIKES Bali pada tahun 2018

I.G.A.B. Adiputra : Kajian Penggunaan Incinerator Untuk.... jumlah limbah medis padat dari 62 fasilitas kesehatan, 120 puskesmas, sekitar 200 klinik bisa mencapai 3 ton perhari.

\section{METODE PENELITIAN}

Dalam melakukan penelitian ini dilakukan langkah langkah seperti gambar berikut

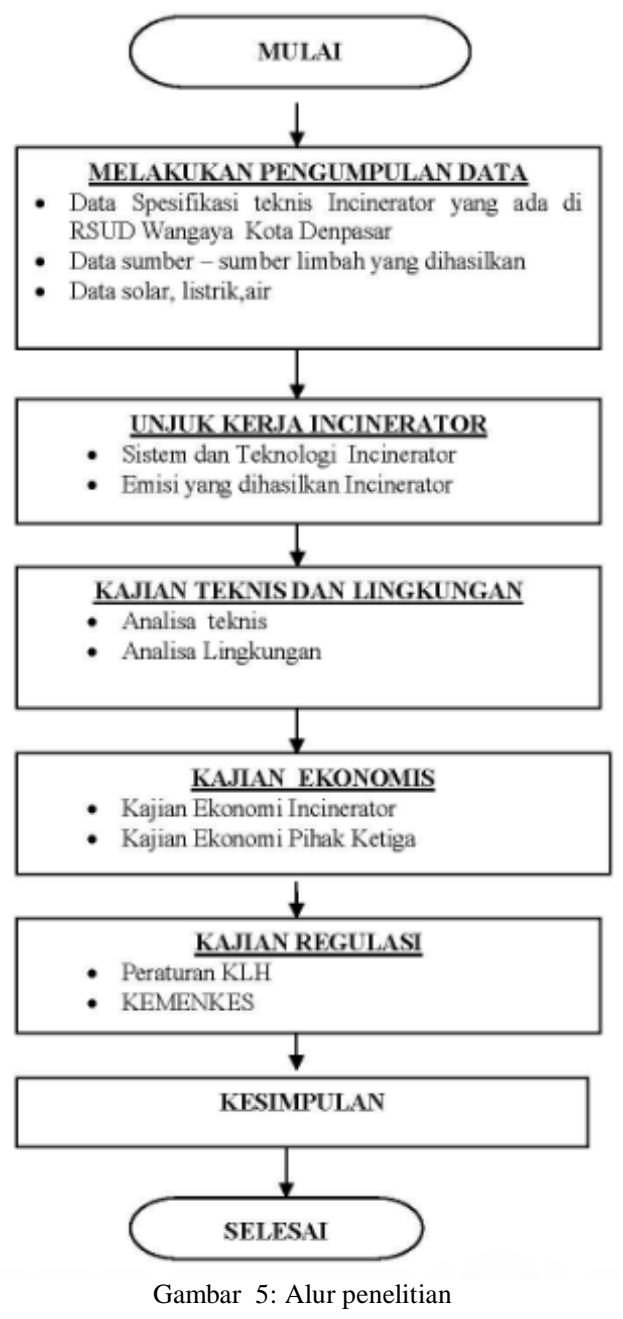

A. Pengumpulan Data

Kegiatan ini dilakukan dengan mengumpulkan data spesifikasi teknis dari incinerator yang ada di RSUD Wangaya, mengumpulkan sumber sumber limbah medis padat yang ada di RSUD Wangaya serta kebutuhan bahan bakar solar, listrik dan air yang diperlukan untuk operasional incinerator

\section{B. Unjuk Kerja Incinerator}

Dilakukan dengan melihat sistim, cara kerja dan teknologi yang dipakai pada incinerator yang ada di RSUD Wangaya serta hasil uji emisi yang dihasilkan dari incinerator ini.

\section{Kajian Teknis dan Lingkungan}


Kajian teknis dilakukan untuk mengetahui apakah incinerator ini sudah memenuhi persyaratan teknis dari KLHK serta mengetahui apakah hasil dari emisi atau gas buang dari incinerator ini aman untuk lingkungan.

\section{Kajian Ekonomis}

Pada kajian ekonomis akan dianalisa apakah pembangunan incinerator ini layak secara ekonomi atau tidak serta bagaimana jika pengelolaan limbah ini dilakukan oleh pihak ketiga atau perusahan pengelola limbah.

Untuk mengukur suatu proyek atau sebuah investas layak atau tidak untuk dikerjakan atau dibangun ada beberapa penilaian yang umum digunakan antara lain metode Net Present Value (NPV), Pay Back Period (PBP), Internal Rate of Return (IRR), Profitable Indek (PI) [10], [11]. Berikut adalah rumus untuk menghitungnya :

$$
\mathrm{NPV}=\Sigma_{\mathrm{t}=1} n \frac{a t-\mathrm{ct}}{(1+1)^{2}}
$$

dengan :

$$
\begin{aligned}
& \text { Bt }=\text { Benefit kotor periode }-\mathrm{t} \\
& \mathrm{Ct}=\text { Cost investasi kotor periode }-\mathrm{t} \\
& \mathrm{n}=\text { nilai ekonomi investasi } \\
& \mathrm{i}=\text { suku bunga rata rata }
\end{aligned}
$$

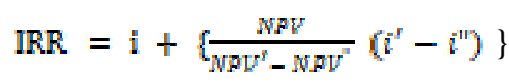

$$
\begin{aligned}
& \mathrm{PBP}=\left(\frac{\text { invanal awal }}{\text { peneriman periodik was bersih }}\right) \\
& \mathrm{PI}=\frac{\text { NaV panerimann }}{\text { NFV pengeluaran }}
\end{aligned}
$$

\section{E. Kajian Regulasi}

Kajian regulasi dilakukan dengan melihat apakah incinerator yang ada di RSUD Wangaya telah memenuhi semua ketentuan yang dipersyaratkan dari KLHK nomer: 56 tahun 2015 dan Peraturan Menteri Kesehatan nomer: 7 tahun 2019.

\section{IV.HASIL DAN PEMBAHASAN}

\section{A. Profil RSUD Wangaya}

RSUD Wangaya Kota Denpasar adalah Rumah Sakit Umum Daerah milik Pemerintah Kota Denpasar, merupakan rumah sakit tipe B pendidikan, beralamat di Jalan Kartini 133 Denpasar. Sebagai rumah sakit pendidikan, RSUD Wangaya juga mengemban misi untuk meningkatkan peran rumah sakit dalam pendidikan dan pelatihan.

Untuk dapat memberi pelayanan kesehatan kepada masyarakat yang paripurna. RSUD Wangaya menyediakan pelayanan dasar, penunjang maupun kegawat daruratan. Pelayanan gawat darurat diperuntukkan bagi pasien yang membutuhkan tindakan medis segera guna penyelamatan nyawa dan kecacatan lebih lanjut. Pelayanan ini diberikan 24 jam 7 hari seminggu. Untuk rawat inap RSUD Wangaya menyediakan 200 tempat tidur yang terdiri dari ruang rawat inap, ruang VIP dan ruang perawatan khusus.

Dalam melaksanakan seluruh aktivitas pelayanannya RSUD Wangaya didukung 961 pegawai yang terdiri dari 92 tenaga dokter, 413 tenaga keperawatan, 103 tenaga medis non keperawatan (farmasi, kesehatan masyarakat, gizi, dan keteknisian medis), 353 tenaga non medis (administrasi, satpam, cleaning service).

\section{B. Pengelolaan Limbah RSUD Wangaya}

Berikut ini adalah proses pengelolaan limbah medis yang dilakukan di RSUD Wangaya.Limbah medis RSUD Wangaya bersumber dari kegiatan pelayanan medis kepada pasien berupa tindakan medis, perawatan medis, dan tindakan penunjang medis lainnya.Untuk menampung limbah hasil kegiatan pelayan medis ini, di tiap ruangan sudah disediakan tempat sesuai dengan jenis limbah. Tempat warna hitam untuk sampah non medis, warna kuning untuk limbah medis padat (infeksius), warna ungu limbah cytotoksik, warna merah untuk limbah radioaktif dan sharp box untuk benda tajam. Limbah yang sudah dipilah dan terkumpul kemudian diangkut ke tempat pengelolaan limbah berdasarkan golongannya, untuk limbah non medis ke TPS limbah domestik diangkut oleh petugas Dinas Lingkungan Hidup dan Kebersihan (DLHK) untuk dibawa ke Tempat Pembuangan Akhir (TPA), sedangkan limbah medis pengolahannya akan dilanjutkan ke incinerator RSUD Wangaya. Limbah cair yang ada di RSUD Wangaya diolah di IPAL yang sudah ada. Berikut adalah alur pengololaan limbah di RSUD wangaya

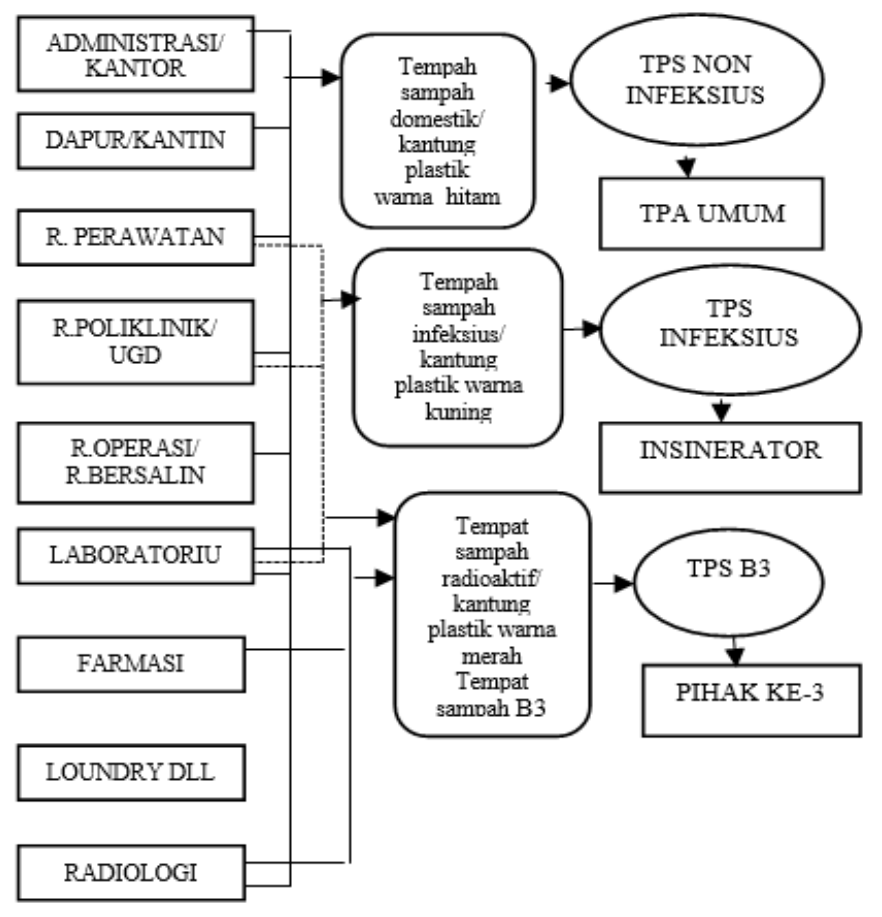

Gambar 6: Alur Pengelolaan Limbah di RSUD Wangaya 
Majalah Ilmiah Teknologi Elektro, Vol. 18, No. 3, September-Desember 2019

DOI: https://doi.org/10.24843/MITE.2019.v18i03.P10

C. Pengembangan proyek pengolahan limbah JICA di Bali

Japan Internasional Cooperation Agency (JICA) adalah lembaga yang didirikan pemerintah Jepang untuk membantu pembangunan negara negara berkembang. JICA mulai melakukan survey di seluruh rumah sakit dan fasilitas kesehatan di Bali tahun 2016, kemudian hasil survei awal RSUD Wangaya dipilih sebagai lokasi proyek. Tahap awal adalah dengan mengajak pihak Badan Pengkajian dan Penerapan Teknologi (BPPT) sebagai wakil dari pemerintah Indonesia dan pemerintah kota Denpasar serta sebagai penerima hibah proyek ini.

Sebagai legalitas proyek maka dibuat Memorandum of Understanding $(\mathrm{MoU})$ yang ditandatangani oleh ketiga pihak yaitu dari JICA, BPPT, dan pemerintah kota Denpasar pada tahun 2016. Proyek mulai dikerjakan pertengahan tahun 2016 dan selsesai bulan desember tahun 2016. Proyek mulai diuji coba dari bulan januari 2017 sampai bulan agustus 2018 . Selama proyek pihak JICA dan BPPT melakukan penelitian penggunaan incenerator ini. Proyek berakhir pada bulan agustus 2018 kemudian dihibahkan ke Pemerintah Kota Denpasar sebagai pemilik RSUD Wangaya.

D. Spesifikasi Incenerator RSUD Wangaya

Berikut adalah spesifikasi incenerator yang ada di RSUD Wangaya Denpasar seperti Tabel II

TABEL II

SPESIFIKASI INCINERATOR DI RSUD WANGAYA

\begin{tabular}{|c|c|}
\hline merek & Chirimeser \\
\hline Model & TG-49 \\
\hline Type & Batch type \\
\hline Buatan & Thomas Technical Co.Ltd \\
\hline $\begin{array}{l}\text { Jumlah ruang } \\
\text { bakar }\end{array}$ & 2 buah \\
\hline Luas lantai tungku & $0,49 \mathrm{~m}^{2}$ \\
\hline Dimensi luar & $1000 \mathrm{~mm} \times 1800 \mathrm{~mm} \times 3600 \mathrm{~mm}$ \\
\hline Dimensi pintu & $450 \mathrm{~mm} \times 700 \mathrm{~mm}$ \\
\hline Voltase & $100 \mathrm{~V} \mathrm{AC}$ \\
\hline Bahan bakar & Solar \\
\hline Jumlah burner & 2 buah \\
\hline Jumlah blower & 2 buah \\
\hline Kontrol panel & ada \\
\hline $\begin{array}{l}\text { Konsumsi bahan } \\
\text { bakar }\end{array}$ & $2-8 \mathrm{~L} / \mathrm{jam}$ \\
\hline Konsumsi listrik & $0,8 \mathrm{kWh}$ \\
\hline Konsumsi air & $6,25 \mathrm{~L} / \mathrm{jam}$ \\
\hline $\begin{array}{l}\text { Kapasitas } \\
\text { pembakaran }\end{array}$ & $\begin{array}{l}\text { Sampah campuran } \leq 45 \mathrm{~kg} / \mathrm{jam} \\
\text { Sampah plastik } \leq 10 \mathrm{~kg} / \mathrm{jam}\end{array}$ \\
\hline Temperatur & $\begin{array}{l}\text { Ruang bakar satu }=800^{\circ} \mathrm{C} \\
\text { Ruang bakar dua }=1.200^{\circ} \mathrm{C}\end{array}$ \\
\hline $\begin{array}{l}\text { Waktu tinggal } \\
\text { limbah dalam } \\
\text { ruang bakar }\end{array}$ & 15 menit \\
\hline Tinggi cerobong & 14 meter dari permukaan tanah \\
\hline
\end{tabular}

E. Unjuk Kerja Incinerator RSUD Wangaya

Sesuai hasil pengamatan selama penelitian di RSUD Wangaya berikut adalah unjuk kerja dari Incinerator Chirimeser TG-49.

1. Efisiensi pembakaran $>99,93 \%$ sesuai dengan hasil uji emisi

2. Suhu ruang bakar utama incinerator chirimeser TG49 berkisar antara $750{ }^{\circ} \mathrm{C}$ sampai $800^{\circ} \mathrm{C}$ sedangkan di ruang bakar yang kedua suhunya $1100^{\circ} \mathrm{C}$

3. Perhitungan waktu tinggal incinerator chirimeser dengan kondisi ruang bakar diisi $100 \%$ sebagai berikut :
a) Temperatur stacck (Ts)
$=253^{\circ} \mathrm{C}$
b) Density gas stack
c) Koefisien pilot tube
d) Volume chamber
e) Tekanan atmospheric
f) Diameter cerobong
g) Tekanan dinamis stack
h) Sampling Port high
i) Velocyty stack
$=0,34^{\circ} \mathrm{C}$
$=0,84$
$=1,25 \mathrm{~m}^{3}$
$=759 \mathrm{mmHg}$
$=40 \mathrm{~cm}, \mathrm{r}=20 \mathrm{~cm}$
$=23 \mathrm{pa}$
$=3800 \mathrm{~mm}$
$=7,8 \mathrm{~m} / \mathrm{s}$
j) Luas penampang cerobong
k) Flow rate $\quad=0,507 \mathrm{~m}^{3} / \mathrm{s}$
1) Waktu tinggal incinerator

$$
=\frac{1,25 \mathrm{~m}^{2}}{0,507 \mathrm{~m}^{2} / \mathrm{s}}=2,47 \mathrm{~s}
$$

4. Incinerator chirimeser TG-49 ini sudah dilengkapi dengan wet scruber sebagai pencegah pencemaran udara

5. Incinerator chirimeser $\mathrm{TG}-49$ ini memiliki ketinggian cerobong setinggi 14 meter dari permukaan tanah dan telah memenuhi baku mutu emisi.

\section{F. Uji Emisi Incinerator RSUD Wangaya}

Incinerator Chirimeser TG-49 yang ada di RSUD Wangaya sudah dilakukan uji emisi untuk mengetahui hasil emisi gas buangnya. Uji emisi dilaksanakan oleh badan independen yang sudah terakreditasi yaitu perusahan Sucofindo. Hasil dari uji emisi incinerator RSUD Wangaya seperti pada Tabel III berikut:

TABEL III

HASIL UJI EMISI INCNINERATOR CHIRIMESER TG-49 RSUD WANGAYA

\begin{tabular}{lllll}
\hline \multicolumn{1}{c}{ Parameter } & \multicolumn{1}{c}{$\begin{array}{c}\text { Incinerator } \\
\text { RSUD } \\
\text { Wangaya }\end{array}$} & $\begin{array}{c}\text { Standar } \\
\text { Indonesia }\end{array}$ \\
\hline Nitrogen Dioksida $\left(\mathrm{NO}_{2}\right)$ & 111.70 & $\mathrm{mg} / \mathrm{Nm}^{3}$ & $300.00 \mathrm{mg} / \mathrm{Nm}^{3}$ \\
\hline Sulfur Dioksida $\left(\mathrm{SO}_{2}\right)$ & 110.90 & $\mathrm{mg} / \mathrm{Nm}^{3}$ & $250.00 \mathrm{mg} / \mathrm{Nm}^{3}$ \\
\hline Karbon Monoksida $(\mathrm{CO})$ & 60.20 & $\mathrm{mg} / \mathrm{Nm}^{3}$ & $100.00 \mathrm{mg} / \mathrm{Nm}^{3}$ \\
\hline Hidrogen Clorida $(\mathrm{HCl})$ & 0.04 & $\mathrm{mg} / \mathrm{Nm}^{3}$ & 70.00 & $\mathrm{mg} / \mathrm{Nm}^{3}$ \\
\hline Parikel & 21.70 & $\mathrm{mg} / \mathrm{Nm}^{3}$ & 50.00 & $\mathrm{mg} / \mathrm{Nm}^{3}$ \\
\hline Total Hidrocarbon $\left(\mathrm{sbg} \mathrm{CH}_{2}\right)$ & 21.50 & $\mathrm{mg} / \mathrm{Nm}^{3}$ & $35.00 \mathrm{mg} / \mathrm{Nm}^{3}$ \\
\hline Hidrogen Flurioda $(\mathrm{HF})$ & 0.04 & $\mathrm{mg} / \mathrm{Nm}^{3}$ & $10.00 \mathrm{mg} / \mathrm{Nm}^{3}$ \\
\hline Timbal $(\mathrm{Pb})$ & 0.12 & $\mathrm{mg} / \mathrm{Nm}^{3}$ & 5.00 & $\mathrm{mg} / \mathrm{Nm}^{3}$ \\
\hline
\end{tabular}




\begin{tabular}{lllll}
\hline Arsen $(\mathrm{As})$ & 0.00 & $\mathrm{mg} / \mathrm{Nm}^{3}$ & 1.00 & $\mathrm{mg} / \mathrm{Nm}^{3}$ \\
\hline Kromium $(\mathrm{Cr})$ & 0.03 & $\mathrm{mg} / \mathrm{Nm}^{3}$ & 1.00 & $\mathrm{mg} / \mathrm{Nm}^{3}$ \\
\hline Kadmin $(\mathrm{Cd})$ & 0.08 & $\mathrm{mg} / \mathrm{Nm}^{3}$ & 0.20 & $\mathrm{mg} / \mathrm{Nm}^{3}$ \\
\hline Merkuri $(\mathrm{Hg})$ & 0.03 & $\mathrm{mg} / \mathrm{Nm}^{3}$ & 0.20 & $\mathrm{mg} / \mathrm{Nm}^{3}$ \\
\hline Talium $(\mathrm{Tl})$ & 0.20 & $\mathrm{mg} / \mathrm{Nm}^{3}$ & 0.20 & $\mathrm{mg} / \mathrm{Nm}^{3}$ \\
\hline Opasitas & 8.0 & $\%$ & 10 & $\%$ \\
\hline
\end{tabular}

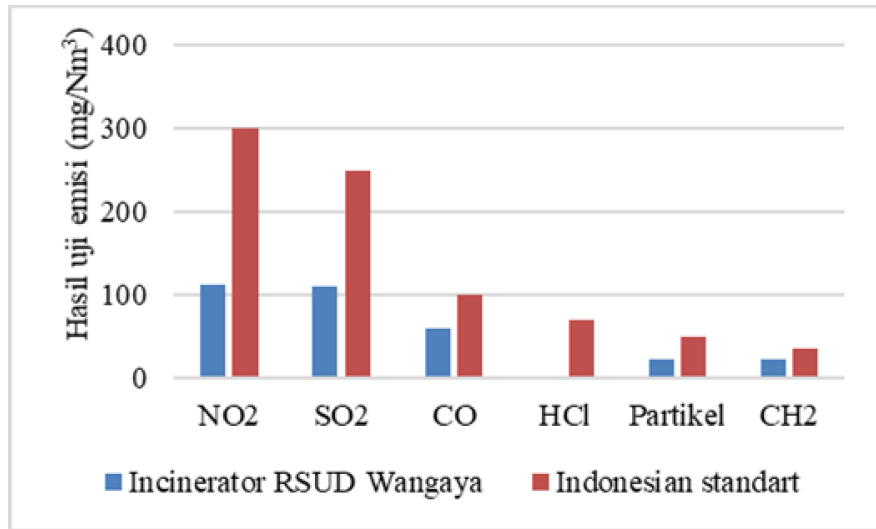

Gambar 7: Grafik hasil uji emisi incinerator

Dari tabel diatas hasil uji emisi incinerator ini hasilnya lebih rendah dari standar yang disyaratkan Kementerian Lingkungan Hidup dan Kehutanan sehingga aman terhadap lingkungan

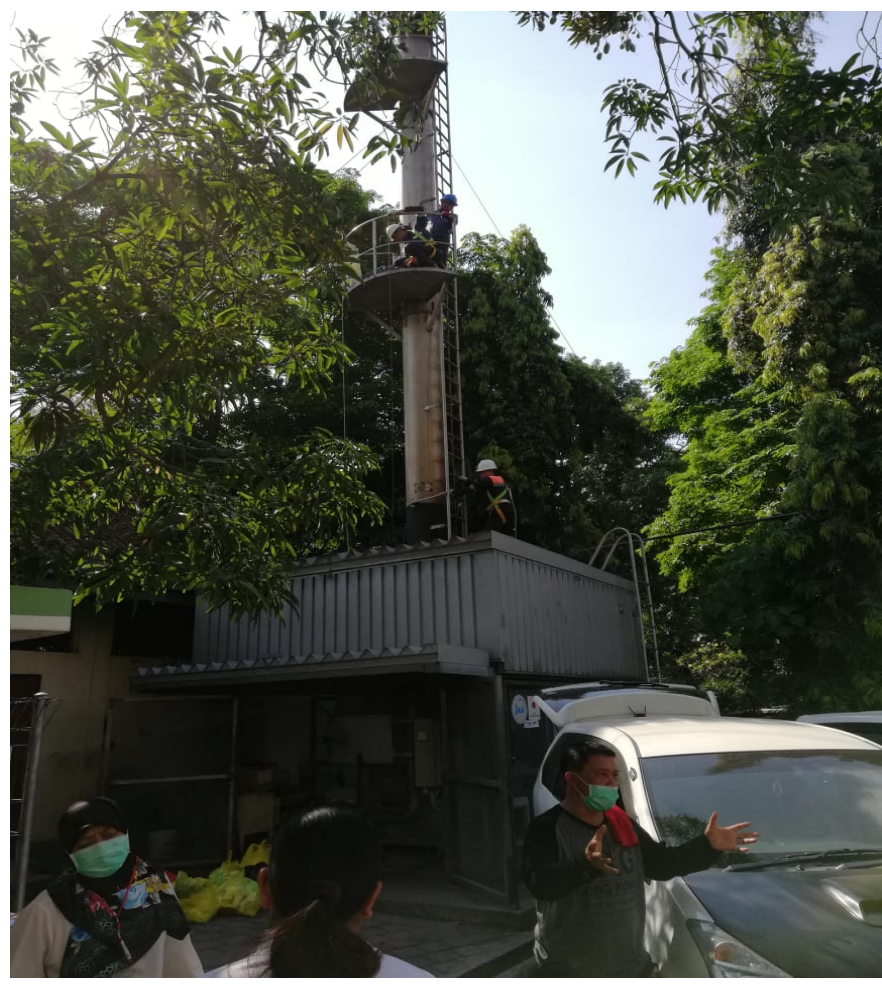

Gambar 8: Pengambilan uji emisi incinerator

G. Analisa Ekonomi Incinerator RSUD Wangaya
Berikut ini analisa kelayakan ekonomi pemasangan incinerator di rumah sakit, pada analisa ini tidak dihitung nilai tanah dan pajak pajak. Pada Tabel IV ditampilkan asumsi asumsi yang dipakai sesuai data yang diperoleh saat penelitian di RSUD Wangaya. Harga jual yang ditampilkan pada tabel tersebut didapat dari harga jual yang dibebankan oleh pihak ketiga, jika RSUD Wangaya mengirim sampahnya ke luar. Sedangkan pada Tabel V asumsi komponen biaya seperti harga solar berdasarkan harga Pertamina saat itu, harga listrik sesuai harga PLN, harga air sesuai harga air PDAM Denpasar, gaji sesuai UMR Denpasar saat itu.

TABEL IV

ASUMSI PERHITUNGAN BIAYA PEMASANGAN INCINERATOR

\begin{tabular}{|c|c|c|c|}
\hline No & Asumsi & Satuan & Total \\
\hline 1 & Investasi & $\mathrm{Rp}$ & 6.7 miliar \\
\hline 2 & $\begin{array}{l}\text { Umur } \\
\text { ekonomi alat }\end{array}$ & Tahun & 15 \\
\hline 3 & $\begin{array}{l}\text { Kapasitas } \\
\text { produksi }\end{array}$ & Ton/Tahun & $45 \times 8 \times 26 \times 12=108$ \\
\hline 4 & Harga jual & $\mathrm{Rp} / \mathrm{Ton}$ & 23,5 juta \\
\hline 5 & Depresiasi & $\mathrm{Rp}$ & $\mathrm{Rp} \quad 446.666 .667$ \\
\hline 6 & $\begin{array}{l}\text { Tingkat suku } \\
\text { bunga bank }\end{array}$ & $\%$ & 10 \\
\hline 7 & Modal sendiri & $\%$ & 100 \\
\hline
\end{tabular}

TABEL V

ASUMSI KOMPONEN BIAYA PEMASANGAN INCINERATOR

\begin{tabular}{llcrrr}
\hline No & Komponen & Satuan & $\begin{array}{c}\text { Harga } \\
(\mathrm{Rp})\end{array}$ & $\begin{array}{c}\text { Kebutuhan per } \\
\text { Tahun }\end{array}$ & Total (Rp) \\
\hline 1 & Biaya solar & Liter & 10.300 & 23.040 & 237.312 .000 \\
\hline 2 & Biaya listrik & KWH & 1.500 & 2.304 & 3.456 .000 \\
\hline 3 & Biaya air & Liter & 1.443 & 18.000 & 25.974 .000 \\
\hline 4 & Gaji 4 orang & Rp & & 174.000 .000 & 174.000 .000 \\
\hline 5 & $\begin{array}{l}\text { Biaya } \\
\text { pemeliharaan }\end{array}$ & Rp & & 100.000 .000 & 100.000 .000 \\
\hline TOTAL & & & & 540.742 .000 \\
\hline
\end{tabular}

Berdasarkan data pada Tabel IV dan V dapat dibuat analisa perhitungan arus kas per tahun pemasangan incinerator di rumah sakit seperti yang ditampilkan pada Tabel VI berikut 
Majalah Ilmiah Teknologi Elektro, Vol. 18, No. 3, September-Desember 2019

DOI: https://doi.org/10.24843/MITE.2019.v18i03.P10

TABEL VI

ARUS KAS OPERASIONAL INCINERATOR RSUD WANGAYA

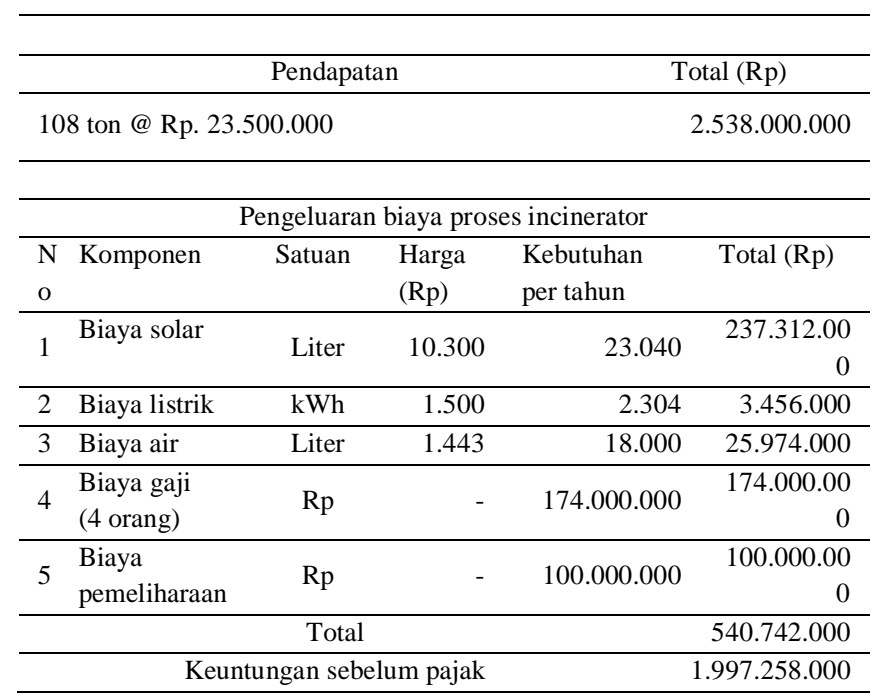

Untuk menentukan sebuah investasi layak atau tidak dibangun ada beberapa kriteria yang harus dipenuhi antara lain: $N P V, I R R, P B P, P I$. Tabel VII berikut adalah nilai $N P V$ dari Pembangunan Incinerator di RSUD Wangaya .

TABEL VII

PERHITUNGAN NPV DENGAN ASUMSI SUKU BUNGA 10\% PADA PEMBANGUNAN INCINERATOR

\begin{tabular}{|c|c|c|c|}
\hline Tahun & $\begin{array}{l}\text { Laba Bersih } \\
\text { (Rp) }\end{array}$ & Faktor PV & $\begin{array}{l}\text { PV } \\
\text { (Rp) }\end{array}$ \\
\hline 1 & 1.997.258.000 & 0,9 & 1.797.532.200 \\
\hline 2 & 1.997 .258 .000 & 0,82 & 1.637.751.560 \\
\hline 3 & 1.997.258.000 & 0,75 & 1.497 .943 .500 \\
\hline 4 & 1.997 .258 .000 & 0,68 & 1.358 .135 .440 \\
\hline 5 & 1.997.258.000 & 0,62 & 1.238.299.960 \\
\hline 6 & 1.997 .258 .000 & 0,56 & 1.118 .464 .480 \\
\hline 7 & 1.997 .258 .000 & 0,51 & 1.018.601.580 \\
\hline 8 & 1.997.258.000 & 0,46 & 918.738 .680 \\
\hline 9 & 1.997.258.000 & 0,42 & 838.848 .360 \\
\hline 10 & 1.997.258.000 & 0,38 & 758.958 .040 \\
\hline 11 & 1.997 .258 .000 & 0,35 & 699.040 .300 \\
\hline 12 & 1.997.258.000 & 0,31 & 619.149 .980 \\
\hline 13 & 1.997 .258 .000 & 0,28 & 559.232 .240 \\
\hline 14 & 1.997.258.000 & 0,26 & 519.287 .080 \\
\hline 15 & 1.997 .258 .000 & 0,23 & 459.369 .340 \\
\hline \multicolumn{3}{|c|}{$N P V$ dengan tingkat bunga $10 \%$} & 15.039 .352 .740 \\
\hline
\end{tabular}

I.G.A.B. Adiputra : Kajian Penggunaan Incinerator Untuk....
Tabel VIII adalah ringkasan analisa investasi pembangunan incinerator cherimeser TG-49 yang didapat dari persamaan (1), (2), (3), (4).

TABEL VIII

KRITERIA PENILAIAN INVESTASI PEMBANGUAN INCINERATOR RSUD WANGAYA

\begin{tabular}{lll}
\hline No & Parameter & Hasil \\
\hline 1 & $N P V$ & 15.039 .352 .740 rupiah \\
\hline 2 & $I R R$ & $33,49 \%$ bulan \\
\hline 4 & $P B P$ & 2,74 tahun \\
\hline 5 & $P I$ & 4,69 \\
\hline
\end{tabular}

\section{KESIMPULAN}

Dari hasil penelitian ini dapat diambil kesimpulan yaitu :

1. Hasil kajian terhadap penggunaan incinerator yang ada di RSUD Wangaya secara unjuk kerja telah memenuhi persyaratan seperti efisiensi $>99,95 \%$, suhu pada ruang bakar satu $800^{\circ} \mathrm{C}$ dan $1100^{\circ} \mathrm{C}$ pada ruang bakar dua, memiliki wet scrubber, ketinggian cerobong sudah 14 meter, dan emisi gas buang sudah memenuhi standar.KLHK.

2. Secara ekonomi pembangunan incinerator di RSUD Wangaya memenuhi kriteria $N P V, I R R, P B P, P I$ sehingga layak untuk dibangun.

3. Incineraor RSUD Wangaya sebagai salah satu solusi untuk pengolahan limbah medis yang ramah lingkungan karena uji emisinya memenuhi syarat dan biaya pengolahan lebih murah.

\section{REFERENSI}

[1] Dinas Kesehatan Provinsi Bali,"Profil Kesehatan Provinsi Bali 2017". Bali. 2018.

[2] K. Kardono, "Environmental Performance Test Of Hazard Waste Incinerator In Indonesia". 2016.

[3] Purningsih, Dewi, "Hanya 93 rumah sakit di indonesia yang memiliki ijin operasional insinerator". Jakarta : Greeners 2018

[4] Peraturan Pemerintah Republik Indonesia Nomor: 12 Tahun 1994 "Pengelolaan Limbah Bahan Berbahaya Dan Beracun". Jakarta. 1994.

[5] Peraturan Pemerintah Republik Indonesia Nomor: 18 Tahun 1999 "Pengelolaan Limbah Bahan Berbahaya Dan Beracun". Jakarta. 1999

[6] Peraturan Pemerintah Republik Indonesia Nomor: 101 Tahun 2014 "Pengelolaan Limbah Bahan Berbahaya Dan Beracun". Jakarta. 2014.

[7] Peraturan Menteri Lingkungan Hidup dan Kehutanan RI nomor: 56 Tahun 2015 "Tata Cara Dan Persyaratan Teknis Pengelolaan Limbah Bahan Berbahaya Dan Beracun Dari Fasilitas Pelayanan Kesehatan". Jakarta. 2015

[8] B.Atework, J.Hanania, K.Stenhouse, J.Donev, Wet Scrubber, diakses dari https://energyeducation.ca/encyclopedia/wet_scrubber, pada tanggal 1 agustus 2019

[9] Ditjen PP \& PL dan WHO. "pedoman Pengelolaan Limbah Medis Tajam di Pusat Kesehatan Masyarakat. Jakarta. 2006

[10] Khotimah, Husnul dan Sutiono, “ Analisa Kelayakan Finansial Usaha Budidaya Bambu" Jurnal Ilmu Kehutanan, Vol 8 No 1 Januari-Maret 2014

p-ISSN:1693 - 2951; e-ISSN: 2503-2372 
[11] I.B.K.Sugirianta, I.A.D.Giriantari, I.N.Satya Kumara, "Analisa Keekonomian Tarif Listrik Pembangkit ListrikTenaga Surya 1 MWP Bangli Dengan Metode Life Cycle Cost " Majalah Ilmiah Teknologi Elektro, Vol 15, 2016 